American Journal of Economics and Business Administration 1 (4): 285-295, 2009

ISSN 1945-5488

(C) 2009 Science Publications

\title{
The Legal Status of Eco-Labels and Product and Process Methods in the World Trade Organization
}

\author{
Jasper Stein \\ The University of Bonn, Rechtswissenschaftliche Fachbereich, Germany
}

\begin{abstract}
Problem statement: The award of eco-labels to environmental friendly products or production and process methods of products is a measure to protect the environment by supporting environmental friendly products. WTO members award eco-labels to combine trade restrictions which are based on environmental protection and the general provisions of the WTO. Approach: This study examined the different types of Eco-labels and their characteristics and their legal status in the WTO. Therefore, this study is divided into three topics. In the first topic, the attributes of Eco-labels will be presented. Results: After that, the next topic deals with the legal status of eco-labels within the WTO and based on this a review of the WTO jurisprudence of products' attributes and products' product and process methods is made. Conclusion/Recommendations: In the last topic, the outcome of the WTO jurisprudence is applied to the legal status of Eco-labels within the WTO. Generally, Eco-labels are applicable to WTO-provisions, as long as they are voluntary.
\end{abstract}

Key words: Eco-labels, PPM, WTO

\section{INTRODUCTION}

The use of environmental friendly labels (eco-labels) aims to protect the environment by suggesting the consumer to buy an environmental friendly product and by encouraging producers to produce more of those products. eco-labels can be awarded based on the environmental friendliness of the product's attributes or based on the product's environmental friendly Production and Process Methods (PPMs).

Since the beginning of the World Trade Organization (WTO), the application of PPMs has been discussed by the jurisprudence of the WTO. In those cases PPMs were related to a member's regulation, which restricted or banned the import of products' PPMs.

Voluntary eco-labels do not restrict or ban the import of a product, but influence consumers' behavior and that might influence the unlabelled products' market access indirectly. This article will give an overview of eco-labels in the WTO and the legal situation of the application of Eco-labels based on PPMs. Eco-labels will be described in general and compared with the view of the former WTO jurisprudence regarding PPMs.

Eco-label attributes: To describe an eco-label, its attributes will be divided into three groups-its objective, its characteristics and its system.

Objective of eco-labels: In general, eco-labels have three intentions ${ }^{[1]}$ :
- To inform the consumer about the environmental friendliness of the product of interest

- To develop environmental standards for the production of the goods

- To protect domestic products

Consumer information: Most environmental damages are based on the consumption of products. To avoid this, the consumers' behavior has to be changed and eco-labels constitute a response ${ }^{[2]}$. The aim of Ecolabels is to suggest consumers to buy environmental friendly products ${ }^{[3]}$. Therefore, the Eco-Label is a noticeable symbol informing the consumer about the environmental friendliness of a product, what otherwise might be difficult to explain to the consumer. For instance, the German 'Blauer Engel' is a simple symbol of environmental friendliness, showing the symbol of an angel, which informs the consumer that this is a friendly product ${ }^{[4]}$. Actually, this symbol as such does not inform the consumer in any way. Only the information campaign about the environmental friendliness of products labeled with this symbol and the difference to environmental unfriendly products-not labeled with this symbol-created the effect of this simple symbol. So, the average consumer knows the environmental friendliness of the labeled product but not how or why it is established ${ }^{[5]}$.

In other words, the eco-label represents a symbol for the consumer that the very product is somehow environmental friendly. The consumer might not know 
what sort of environmental protection this product supports, however, as long as it is environmental friendly and the consumer can help to protect the environment by buying this product, the goal of the eco-label is achieved.

Improvement of the environmental friendly production and process: Another objective of ecolabels is the improvement of the environmental friendly production and process of a product, by enhancing its environmental standards, so that eco-labels aim to protect the environment.

Eco-labels provide standards, which have to be met by all productions and processes of products, in order to get labeled with it. Thus, producers with the intention of getting a specific eco-label will have to change their production or process in that way, that the product will be environmental friendly and meet the provided standard. This will lead to a partial improvement of environmental friendly production and process ${ }^{[6]}$. This might cause a general rise of environmental friendliness of all products of the product group, as the competing producers might follow this process change. According to this, the output of environmental unfriendly products would be reduced ${ }^{[7]}$. Hence, the objective of the improvement of the environmental friendly production and process of a product would be met.

Protection of domestic products: Eco-labels could be used by countries to benefit the sale of domestic products by awarding eco-labels mostly to domestic products. This can be enhanced by governments, which for example enact regulations supporting only the labeled products ${ }^{[8]}$. The use of eco-labels could further benefit domestic products as the criteria by which Ecolabels are awarded would not be relevant in the domestic country. That is the Eco-Label is awarded for the protection of an environmental issue, which does not influence the production or process in the domestic country, as these criteria are not relevant for the domestic product, but yet for foreign products ${ }^{[9]}$.

Apart from the environmental protection, those eco-labels would force the domestic products, because governmental regulations and the award of an EcoLabel might lead to a rising amount of sold domestic products.

Characteristics of eco-labels: Eco-labels have two different characteristics, being voluntary or mandatory. Whilst the latter has an obligatory effect on all products of the same category, the first one works in a nonbinding nature, because it might only change the production or process of this product's group.
On the one hand, the use of a voluntary Eco-Label is optional for each company. It is up to the company, if it might apply for the label or leave the product unlabeled. Regardless of how the decision of the company might be, the voluntary Eco-Label affects only the product. The consumer is able to decide, whether he buys the labeled product and hence might protect the environmental or not. The important fact is that the company is not forced to apply for this EcoLabel, but still can decide about its own management.

On the other hand, mandatory Eco-labels do not offer this freedom of decision. In the case of the existence of a mandatory Eco-Label, every product of the product group has to meet the environmental criteria as they are required for the award of the Eco-Label. According to this, market access is not given to those products of producers, who are not willing or able to ensure that those criteria are met by their products.

As for environmental protection, the environmental outcome of mandatory Eco-labels is more effective than the environmental outcome of a voluntary Eco-Label. Voluntary Eco-labels are awarded on an average to 1020 percent of the significant products ${ }^{[10]}$. According to this, the protection of the environment is not covered by each product of this product group. However, mandatory Eco-labels are binding for each product of the product group and hence, by covering the entire product group the provisions of the environmental protection are fulfilled.

Eco-label system: The international organization for Standards has established three different types of Ecolabels:

Type I label: Type I (compare with ISO 14 024) labels are third party programmes, developed by governmental organizations or private non-commercial organizations. This label is voluntary and the product and manufacturing process has to meet multiple environmental provisions, so called life-cycle or PPM analysis. Products will be labeled by type I Eco-labels, if they have met the provisions of scientific criteria ${ }^{[11]}$.

Type II label: The second type of labels (type II) (compare with ISO 14 021) is awarded by the industry association or company itself. It is an international standard, called "self-declaration", which is a singleattribute programme. This type of Eco-Label deals only with one specific attribute of a chosen product and not with the life-cycle analysis. It can be mandatory or voluntary.

Type III label: Type III (compare with ISO/TR 14 025) eco-labels are voluntary programmes, which 
provide quantified information about a product, under an agreed set of parameters. These parameters, based on a life-cycle analysis, are awarded by a third party, which provides selected data about environmental impacts of the product.

The objectives of eco-labels are to influence the behavior of consumers, to enhance the environmental friendliness of the production and the process of a product and to protect the domestic market. With regard to the enforcement of these objectives, eco-labels can be mandatory or voluntary. Furthermore, an Eco-Label has to have one of the characteristics of three different types, which differ in inter alia the requirement of an environmental friendly life-cycle. If the use of an EcoLabel with these different attributes is required the main aim of it is the protection of the environment.

\section{Eco-labels within the WTO:}

General overview: In the beginning of the GATT 1947, the term 'environment' was not mentioned in any legal text of the organization. This was based on the fact that at that time, environmental issues were not relevant for the parties of the GATT 1947 (Multilateral environmental issues became more relevant in the 1970s, when first concerns about the environment were made). But several GATT 1947 articles had a direct relevance for environmental issues, inter alia article I and III of the GATT 1947 regarding non-discriminating effects. article XX of the GATT 1947 as the general exception clause indirectly covered environmental issues.

In 1995, after the introduction of the WTO, environmental issues were covered in several WTOAgreements. For instance, through the provisions of the Marrakesh Agreement establishing the world trade organization in its preamble the environment is addressed by the objective to achieve sustainable development and protection and preservation of the environment. Other WTO-Agreements imply environmental issues in their special provisions, as the article XX of the GATT, the Technical Barriers to Trade (TBT)-Agreement, the agreement on agriculture, the Subsidies and countervail agreement, article 27 of the TRIPS-Agreement and article 14 of the GATS.

\section{The legal status of eco-labels in the WTO:}

Committee on trade and environment: The provisions for Eco-labels are discussed in two committees of the WTO. Since the beginning of the WTO, the Committee on Trade and Environment (CTE) was established to discuss relevant trade issues regarding the environment. Discussions in the CTE deal with trade distorting effects like subsidies or the market access. The CTE also discuss the application of Ecolabels and its objectives, whether these Eco-labels should be awarded for products or even for the production and process method. Item 3 (b) of the Uruguay round agreement-decision on Trade and environment addresses the CTE by discussing the relation between the multilateral trading system and the requirement for environmental purposes relating to products, including inter alia labeling. Hence, labeling, including eco-labels, is a part of the CTE's work programme, which was also underlined by the Doha Ministerial conference in 2001, at which the CTE got the order for a special focus on this issue ${ }^{[12]}$.

Technical barriers to trade committee: The Technical Barriers to Trade (TBT) committee also discusses eco-labels under the provisions of the TBTAgreement. According to the TBT-Agreement, which covers inter alia product standards and labeling, Ecolabels are added to it as well. The TBT Committee debated labeling at the "TBT learning event on labeling" in October 2003 at which the use of Ecolabels within the WTO was conferred based on several case studies. The participating members agreed in the fact that the use of Eco-labels according to market access should be as least trade restrictive as possible and that the TBT provisions would be the appropriate agreement to regulate Eco-labels.

Agreements relating to eco-labels: The fact that ecolabels are discussed in two committees of the WTO creates uncertainty about which WTO provisions might apply for eco-labels. As long as both committees feel responsible for this issue, eco-labels within the WTO have to be analyzed under a broad view of provisions of WTO-Agreements. For this analysis, the provisions of the TBT-Agreement and the GATT will be examined.

Eco-labels in the view of the TBT-Agreement: According to the TBT-Agreement, eco-labels have to meet the following provisions:

Transparency: Eco-labels must be transparent for domestic and foreign producers ${ }^{[13]}$. If an Eco-Label is not sufficiently transparent, producers will find it difficult to apply for its award as they do not know what this label deals with.

Mostly, eco-labels are a part of a national environmental policy and do not have significant trade effects, as long as they are voluntary ${ }^{[14]}$. However, there may be Eco-labels, which could be preferably awarded to domestic producers by offering information about the Eco-Label, which foreign producers might not be given. 
In that case, the domestic producer benefits from the non-transparent Eco-Label, because he can change his product's attributes or PPMs in that way that the domestic product might be awarded with an Eco-Label whilst the foreign will not.

According to this, the provisions of the TBTAgreement oblige WTO Members to set up enquiry points to provide information for and answer queries from interested parties of other WTO Members on technical regulations, standards and conformity assessment procedures, Article 10.1 and 10.3. In further provisions of the TBT-Agreement, WTO Members are obligated to notify technical regulations and conformity assessment procedures prepared by central and local governmental bodies to other members through the secretariat of the WTO (Compare with: Articles 2.9, 2.10, 3.2, 5.6, 5.7 and 7.2 of the TBT-Agreement).

Non-Discrimination: The provisions of the TBTAgreement oblige WTO Members to accord with the principles of the most-favoured-nation treatment and national treatment to imported products. Articles 2 to 4 of the TBT-Agreement provide these principles to create the same standards and regulations for domestic and foreign producers. In providing these principles, the provisions of the TBT-Agreement underline the principle of non-discrimination in the WTO regulation.

Harmonisation and mutual recognition of ecolabels: National Eco-labels might be distorting, if each country's provisions of Eco-labels differ from other country's provisions. If producers would offer their products in different countries they had to adapt all particular national provisions to their product or the product's PPM, which created at least higher costs for them. Or, with regard to the change of the PPM, offering products in different countries could be impossible for the producers, because they could not change the PPM for each Eco-Label. To avoid this, the provisions of the TBT-Agreement encourage in Articles 2.4, 2.5 and 2.6 the WTO Members to apply international standards for their technical regulation. In Article 6 of the TBT-Agreement WTO Members are encouraged to the mutual recognition of conformity assessment by central government bodies. Both provisions, the application of international standards and the mutual recognition of conformity, would cause a reduction of production costs and would lead to improved information of consumers. The reason therefore is that the international regulations could on the one hand enable the consumer to compare Ecolabels from different countries and their producers, which would lead to a greater awareness of each Eco-
Label. On the other hand, Eco-labels enable the producers to change their product or PPM into a similar form of labels by encouraging WTO Members to accept the mutual recognition ${ }^{[15,33]}$.

Eco-labels in the view of the GATT: One of the core elements of the WTO is the principle of nondiscrimination. This principle is regulated in the Articles I, III and XI of the GATT.

According to Article I of the GATT, the obligation for all Members is that all foreign "like products" are treated no less favorable than preferred foreign "like products". Under Article III of the GATT, each Member is obliged to treat foreign originated "like products" "no less favorably" than domestic ones. Article XI of the GATT contains a prohibition of the use of quantitative restrictions on the import and export of goods. The principle of the equal treatment of "like products" affects the application of PPMs as well as product characteristics, because bans on a "like product" would violate the WTO principle of nondiscrimination. If, as it was pointed out in the USShrimp and Turtle case (WTO United states-import prohibition of certain shrimp and shrimp products (USShrimp/turtle), report of the panel, WT/DS58/R; WTO United States-Import Prohibition of Certain Shrimp and Shrimp products (US-Shrimp/Turtle), Report of the appellate body, WT/DS58/AB/R), methods of catching shrimps with turtle friendly nets are allowed under national provisions and the catch of shrimps with turtle unfriendly methods is prohibited and both are "like products", the PPMs violate provisions and cannot be applied WTO conform by members. If the question of unequal treatment of "like products" based on the application of product's PPMs or product's attributes has to be discussed, both forms have to be viewed under one of the above named three articles of the GATT.

The distinction between products and product and process methods: As eco-labels are concerned with how a product is environmental friendly or how its production and process methods are environmental friendly, eco-labels are divided into two categories as well-product related eco-labels and Production and Process Methods (PPMs) related eco-labels. Eco-labels based on the product attributes relate to the characteristics of the products themselves and Ecolabels dealing with PPMs are based on the way in which a product is produced or processed in its country of origin. The Dispute Settlement Body (DSB) has discussed product related measures as well as PPMs measures in several decisions, but without discussing 
Eco-labels. To analyze the legal status of Eco-labels within the WTO, these DSB's decisions will be discussed first. After that, the jurisprudence of those issues will be transferred to Eco-labels to point out the possible solution for a jurisprudence dealing with this issue.

Those WTO-cases dealt with national measures of WTO Parties containing import restriction or ban of environmental unfriendly products. In doing so, two differentiations of the reason for import restrictions had to be decided, based on the product's attributes or on the product's production or process methods.

Import restrictions on product's attributes: At first, cases of the GATT and WTO DSB's dealing with import bans based on product attributes, such as cases like the Thailand-Cigarettes ${ }^{[16]}$, the US-Gasoline ${ }^{[17]}$, the EC-Hormones $^{[18]}$ and the EC-Asbestos ${ }^{[19]}$ will be analyzed.

Thailand-Cigarettes: The first relevant case was the Thailand-Cigarettes case, in which Thailand's prohibition of the import of cigarettes in the light of article XX (b) of the GATT was discussed. Thailand applied restrictions against mainly imported USproduced cigarettes under the exception of Article XX (b) of the GATT, holding that this was based on health concerns because of chemicals and other additives contained in US cigarettes made them more harmful than Thai cigarettes.

Besides the Panel's finding about the import restriction's inconsistency with article XI: 1 of the GATT and not justification under article XI: 2 (c) of the GATT it further examined the exception under Article XX (b) of the GATT and stated:

"that smoking constituted a serious risk to human health and that consequently measures designed to reduce the consumption of cigarettes fall within the scope of article XX (b)" and continued that:

"this provision clearly allowed contracting Parties to give priority to human health over trade liberalization; however, for a measure to be covered by article XX (b) it had to be "necessary"

The Panel continued with arguing about the term 'necessary' and stated, that Thailand had used an unnecessary measure, because there had been other alternative instruments-for instance: non-discriminatory labeling regulations or a ban on advertising (Thai
Cigarettes, BISD 37 S/200-228 § 75). Hence, the Panel pointed out, that this import restriction was not necessary with regard to Article XX (b) of the GATT and could not be an exception under this GATT provision.

According to this case, the Panel did not accept trade distorting measures of discrimination because of product relevant attributes.

US-Gasoline: In a further decision, after the establishing of the WTO, the Panel had to decide another case, which dealt with import restrictions based on product attributes, the US-Gasoline dispute. In that case, the US applied import restrictions by using strict rules on chemical attributes of imported gasoline, which the US did not require for domestic gasoline. Venezuela, as the complaint, argued that those measures were against the WTO national treatment principles, article III of the GATT and would not be excepted by article XX (b) and (g) of the GATT.

The WTO Panel argued again using the term 'necessary' of Article XX (b) of the GATT and pointed out, that the US import restriction would not violate GATT provisions, if there were no consistent or no less inconsistent measures available to the US, to avoid such kind of import restriction (US-Gasoline, WT/DS2/R, Para 6.24). However, the Panel found that the US did not apply less restrictive measures and therefore, article XX (b) of the GATT was not applicable.

Furthermore, the Panel discussed the import restriction under Article XX (g) of the GATT, which relates to national measures "relating to the conservation of exhaustible natural resources, if such measures are made effective in conjunction with restriction on domestic production or consumption" (article XX (g) GATT). The US argued inter alia that foreign gasoline would not meet the provisions of the clear air act and hence, the natural resource "air" had to be conserved by import restrictions on air unfriendly gasoline. The panel found, like in other cases before ${ }^{[20]}$ that the interpretation of the term "related to" the protection of an exhaustible natural resource should be interpreted as "primarily aimed at" such a protection. Consequently, the interpretation of the term "made effective in conjunction with restrictions on domestic production or consumption" should be seen as "primarily aimed at rendering effective these restrictions". Based on this, the panel did not adapt article $\mathrm{XX}(\mathrm{g})$ to the import restriction, because the import of foreign gasoline "would not in any way hinder the United States in its pursuit of its conservation policies" (US-Gasoline, WT/DS2/R, Para. $6.40)$. 
According to this, the Panel neither applied Article XX (b) nor ( $\mathrm{g}$ ) of the GATT in the US-Gasoline case so that the US measure was unjustifiable with Article III: 4 of the GATT.

The appellate body confirmed the interpretation of the term "relating to" as "primarily aimed at", but disagreed with the Panel's finding about "primarily aimed at rendering effective these restrictions" and rather interpreted it as "the measures concerned impose restrictions, not just in respect of imported gasoline but also with respect to domestic gasoline". That is, the appellate body concluded the import restriction under the exception of article XX (g) of the GATT and agreed with the argumentation of the US, that "air" is a part of the conservation policy. But, after the Appellate Body concluded the import restriction under Article XX (g) of the GATT, it did not confirm it under the Chapeau of article XX of the GATT because of "unjustified discrimination" and a "disguised restriction to international trade" ${ }^{,[17]}$.

EC-Asbestos: In the EC-Asbestos case, a French national regulation banned "the manufacture, import, domestic marketing, exportation, possession for sale, offer, sale and transfer under any title whatsoever of all varieties of asbestos fibers or any product containing asbestos fibers" for the protection of workers and consumers (EC-Asbestos, WT/DS135/R, Para. 2.4).

Canada claimed in this case, that the French regulation constituted a technical regulation and that this was incompatible with provisions of the Agreement on Technical Barriers to Trade (TBT-Agreement) and furthermore, it was incompatible with Article III: 4 of the GATT without justification under the exception of Article XX (b) of the GATT.

The Panel stated inter alia that asbestos fibers and products, as based on scientific evidence, cause a risk on the one hand for public health and on the other hand for workers (EC-Asbestos, WT/DS135/R, Para. 8.222). Based on this, the relevant regulation met the provisions of article XX (b) of the GATT by protecting human life or health, because it was a necessary measure and other measures would not reach that goal of protecting human life or health. Hence, the Panel concluded that the French regulation was excluded from Article III: 4 of the GATT by Article XX (b) of the GATT.

The Appellate Body emphasized the Panel's finding by stating:

"the chosen level of health protection by France [was] a 'halt' to the spread of asbestos- related health risks" (EC-Asbestos, WT/DS135/AB/R, Para. 168)

And therefore, the import ban of products containing asbestos was appropriate and proportionate, because there was no other alternative measure available to France. In this decision, the Appellate Body acknowledged the Panel's view that national regulations of France are conform to the WTO provisions. Hence, the DSB accepted a Member's provision, which dealt with import restrictions justified by environmental issues.

The jurisprudence of the WTO demonstrates that product attributes are in general corresponding to WTO-provisions ${ }^{[21]}$. But, as mentioned in the USGasoline case, it has to meet all provisions, like the Chapeau of article XX of the GATT. As the DSB pointed out, the measure of import restrictions or bans must be an appropriate and proportionate measure to be applied in the WTO and they are accepted as long as there is no discrimination of foreign products by their implementation $^{[22]}$.

Import restrictions on production and process methods: The dispute settlement body also had to deal with process and production methods, such as in the Canada-Herring and Salmon case ${ }^{[20]}$, the USTuna/Dolphins case ${ }^{[23]}$ and the US-Shrimp/Turtle case $^{[24]}$.

Canadian herring and salmon: The first case regarding the PPMs in environmental issues was the Canadian Herring and Salmon case, which was invoked before the GATT dispute settlement authorities. The US complained against Canadian regulations (These regulations were: Sub-section 34 (j) of the Canadian Fisheries Act of 1970, paragraph 6 of the Pacific Commercial Salmon Fishery Regulation and paragraph 24 (1) of the Pacific Herring Fishery Regulation), which stated that salmon and herring, caught in Canadian territory had to be processed in Canada before being exported. Canada explained that those measures were part of the Canadian management scheme of fishery resources and that it would be "related to the conservation exhaustible natural resources", article XX (g) of the GATT.

The panel replied to the Canadian argument with an interpretation of Article XX (g) of the GATT exception by stating, that the Article XX (g) of the GATT was not created to widen its:

"scope for measures serving trade policy
purposes but merely to ensure that the 
commitments under the General Agreement do not hinder the pursuit of policies aimed at the conservation of exhaustible natural resources" $"[25]$

The panel concluded further that:

"while a trade measure did not have to be necessary or essential to the conservation of an exhaustible natural resource, it had to be primarily aimed at the conservation of an exhaustible natural resource to be considered as "relating to" conservation within the meaning of Article XX (g) of the GATT. The Panel, similarly, considered that the terms "in conjunction with" in Article XX (g) had to be interpreted in a way that ensures that the scope of possible actions under that provision corresponds to the purpose for which it was included in the General Agreement. A trade measure could therefore in the view of the Panel only be considered to be made effective "in conjunction with" production restrictions if it was primarily aimed at rendering effective these restrictions." (ibid)

According to this, the panel underlined that the Canadian regulation was non-compliant with the provisions of Article XX (g) of the GATT, because it was not "primarily aimed at" the conservation of the amount of salmon and herring and "was not primarily aimed at rendering effective these restrictions" (Ibid, at Para. 4.7). The Canadian regulations "were not conservation measures per se but [...] increase the benefits to the Canadian economy arising from the Salmonid enhancement program." (ibid) With regard to the restriction of the process method by Canada, the panel decided that "Canada limits purchases of unprocessed fish only by foreign processors and consumers and not by domestic processors and consumers", because the Canadian restriction did not restrict Salmon and Herring in general but only to unprocessed salmon and herring (ibid). Hence, the panel found that these restrictions would rather prefer the Canadian economy instead of conserve the salmon and herring, so that the restrictions of the Canadian process method were not justifiable.

US-Tuna/Dolphin: Again, in the US-Tuna/Dolphin I case $^{[25]}$ the Panel had to discus the PPMs, as the US restricted the import of yellow-fin tuna and yellow-fin tuna products from Mexico on the basis of animal health and life considerations (The US import restriction was provided under the US 1972 Marine Mammal protection Act). The US alleged that the Mexican fishermen's method of catching yellow-fin tuna with the use of purse-seine nets caused a high level of dolphin mortality and therefore the import of tuna and tuna products, caught this way was restricted.

The panel stated that the US restrictions on the import of tuna and tuna products on the basis of how the Mexican fishermen were producing tuna were nonjustifiable within the content of Article III and Article XI: 1 of the GATT. The Panel concluded that the US measures were also not covered by the exception of article XX (b) and (g) of the GATT. With regard to Article XX (b) of the GATT, the panel interpreted the US measure under the term 'necessary' and analyzed, whether the US had used other appropriate measures, as the Panel did before in the Thai-Cigarettes case. The Panel found that the US had failed to demonstrate that other measures consistent with the GATT were not available to it to pursue the protection of dolphins (USTuna/Dolphin I, Para. 5.28).

According to the exception under Article XX (g) of the GATT, the Panel underlined that it would only be justified, if the country "controls the production or consumption of an exhaustible natural resource only to the extent that the production or consumption is under its jurisdiction". Further, the panel stated "that article $\mathrm{XX}$ (g) was intended to permit contracting parties to take trade measures primarily aimed at rendering effective restrictions on production or consumption within their jurisdiction" (Ibid at Para. 5.31). To fall under the exception of article XX (g) of the GATT, the US measure had to restrict the production or consumption, which was regulated within the US jurisdiction. However, the US had restricted the import of tuna and tuna products, which were produced out of the jurisdiction of the US. Accordingly, the US measure did not fall under the exception of Article XX (g) of the GATT and the Panel did not justify the measure.

US-Shrimp/Turtle case: In another case, the United States were again the respondent in which US regulations impose a fishing method, so called "turtle excluder devices", to prevent the accidental taking (In this context, 'take' means: harassment, hunting, capture, killing or attempting to do any of these) of sea turtles in connection with fishing activities occurring outside the jurisdiction of the United States (USShrimp/Turtle, Para. 2.7). This case also dealt with PPMs, as the methods of catching shrimps was regulated by national US regulations.

The panel constituted that the US regulation was against article XI of the GATT, because the US used 
import prohibitions or restrictions which are prohibited by article XI: 1 (Ibid at Para. 162). Further, the panel argued that the application of article XX (b) or ( $g$ ) of the GATT was not part of this case. According to this, the measure of the US was not justified under GATT rules.

The appeal at the appellate body came to another view than the panel did. It found that the national measure of the United States was not consistent with article XI: 1 of the GATT, either, but continued that it was justifiable under the exception of article XX (g) of the GATT. In the view of the appellate body, the scope of the national import restrictions was not too wide and it was appropriate to the relation of the objective of protecting and conserving turtles (WTO, Appellate Body US-Shrimp and Turtle, at Para. 141). Accordingly, the appellate body justified a restriction based on PPMs under article XX (g) of the GATT.

Conclusion of the WTO jurisprudence: In the first PPM cases, the view of the GATT and WTO jurisprudence was refusing towards PPMs. The DSB prohibited the application of import restriction based on the production or process of a product, because this was on the one hand against article I, III and/or XI of the GATT and on the other hand not covered by Article XX (b) or ( $g$ ) of the GATT or of the Chapeau of article $\mathrm{XX}^{[26]}$.

In a later decision, the US-Shrimp and Turtle case, the DSB justified the application of PPMs under the exception of Article XX (g) of the GATT insofar as it was "not disproportionately wide in its scope and reach in relation to the policy objective of protection and conservation of sea turtle species. The means are, in principle, reasonably related to the ends" (WTO, Appellate body US-Shrimp and Turtle, at Para. 141). That is, environmental PPMs are not prohibited by the WTO, but applicable, when appropriate. Hence, for future cases, the application of Members' measures, which might restrict the import based on environmental incompatibility of a special good's characteristics, could be under special circumstances conform to WTO provision $^{[27]}$.

The WTO-jurisprudence in the view of product related eco-labels: The objectives of eco-labels as other environmental protection measures may not fall under WTO provisions. As mentioned above, Ecolabels can be awarded for the environmental friendliness of a product or of the whole life-cycle, the product and process method. Members, which award eco-labels, might violate other members' rights by discriminating them through restricted market access.
Hence, the application of eco-labels within the WTO can lead to disputes. To point out the justification of eco-labels, the jurisdiction of the abovementioned decisions of the DSB has to be transferred to the application of Eco-labels. Therefore, the outcome of the WTO-jurisprudence regarding products' attributes and products' PPMs has to be seen with regard to characteristics of a mandatory as well as a voluntary Eco-labels.

Mandatory eco-labels: Mandatory eco-labels are binding for all products of one product group and are alike to import restrictions or bans in that way that producers, refusing the provisions of offering an environmental friendly product, cannot get market access in the labeling country.

In that case, mandatory eco-labels have to comply with all WTO regulations, including provisions of the TBT-Agreement and the GATT. The jurisprudence of the DSB with regard to the products' PPMs and products' attributes will apply as a whole. That is, mandatory Eco-labels have to meet the provisions named in the jurisprudence. If the mandatory Eco-Label violates provisions of the WTO regulations, an excuse under article XX (b) or (g) of the GATT might apply, but again, it has to meet those provisions and also the Chapeau of article XX GATT. According to the interpretation of the DSB in product related cases of Article XX (b) and (g) of the GATT, mandatory Ecolabels must meet the criteria of being appropriate and proportionate. Furthermore, it has to be 'necessary' and by analyzing that fact, the application of a mandatory Eco-Label is conform with WTO provisions, if there is no consistent or inconsistent measures reasonable available, article XX (b) of the GATT. In the view of article XX (g) of the GATT, mandatory eco-labels are covered from this provision, if they are "relating to" like the DSB interpreted this term, "the protection of an exhaustible natural resource, Article XX (g) of the GATT.

Voluntary eco-labels: The application of voluntary eco-labels in the WTO is different to the application of mandatory eco-labels. The voluntary eco-label is of less impact, which is similar to an import restriction or ban $^{[28]}$. This is based on the fact, that those eco-labels are voluntary and the producer of the product which might be labeled has the choice to fulfill the provisions of the eco-label or not. Furthermore, a voluntary ecolabel does not affect a product in that way, as mandatory Eco-labels or import restrictions do. A company, which exports non labeled products to the relevant country, is not at risk to not selling its 
products. As pointed out above, those products might be sold for a lower price than those with an eco-label. But again, the company can still sell the product in the relevant country. Voluntary eco-labels are awarded only to 10 to 20 percent of the environmental friendliest products ${ }^{[27,29]}$. According to this, the bulk of offered products on the market are unlabelled. Hence, there are still opportunities for everyone, to sell the environmental unfriendly product in the relevant country. But, eco-labels might affect, but not discriminate markets. As long as eco-labels are voluntary, there are consumers, who might not be willing to pay the higher price for environmental protection, which is entailed with buying eco-label products $^{[30]}$.

According to this, a voluntary eco-label awarded to product's attributes can be viewed as a consistent or inconsistent measure, which is 'reasonable available' for a WTO Member to protect the environment with corresponding WTO provisions, as it was suggested in the Thai-Cigarettes case with a health-label which could have shown the danger of smoking.

The award of eco-labels to solely environmental friendly products conforms to WTO provisions. National provisions to protect the environment with import restrictions based on an environmental unfriendly product's attribute are permitted by WTO agreements, as long as they are voluntary, market-based and transparent ${ }^{[31]}$.

With regard to voluntary Eco-labels, awarded to the product's PPMs, the application has to be narrower than it is for voluntary eco-labels relating to product's attributes. The PPM Eco-Label could not be awarded on that fact, that the PPMs do not cover the necessary provisions of the Eco-Label, even if the product might be environmental friendly. This could inter alia protect domestic products, because those products could be produced under different conditions, as foreign products are.

In that case, the complete arguments of the jurisprudence for PPMs have to be applied. Even if the eco-label covers only 10-20 percent of the market's product, those products, which did not meet the provisions of the Eco-Label because of a different PPM, might be discriminated. In that case, the voluntary eco-label has to meet the exception under article XX (b) and (g) of the GATT as well as the Chapeau of article XX of the GATT (For the provisions of article XX (b) and (g) GATT, compare with the mandatory eco-labels).

In other words, voluntary eco-labels, which are awarded, based on product's attributes, have to meet the criteria of being transparent, market-based and voluntary (Compare with the above described provisions in paragraph: 'eco-labels in the view of the TBT-Agreement'). Product's PPMs awarded voluntary Eco-labels have to meet more provisions, as they have to fulfill the same criteria as mandatory eco-labels do. This is based on its environmental provisions for the production and process method in a foreign country, which can be discriminating, because inter alia a country has not the same production conditions as the awarding country (Compare with above described protection of domestic products).

\section{CONCLUSION}

After the relevant facts about eco-labels have been pointed out in this study, a discussion of the products' attributes and PPMs in the past WTO jurisprudence has been presented. The outcome of this jurisprudence has been transferred to the application of Eco-labels within the WTO.

Eco-labels are applied to label products as environmental friendly and suggest the consumer that the purchase of these products would help to protect the environment. But Eco-labels can also be awarded on basis of PPMs. As conducted above in the jurisprudence of the WTO in particular cases, the import ban based on PPMs was violating GATT provisions and could no longer be applied by Members. However, in the US-Shrimp and Turtle case, PPMs also violated provisions of the GATT, but were covered by article XX (g) of the GATT.

As a result of this research, it can be stated that in general, PPMs of products are not prohibited in the WTO. They are permitted as long as these methods are not violating WTO provisions or as long as they are covered by the exception of Article XX (b) and (g) of the GATT.

With regard to eco-labels based on PPMs, the DSB jurisprudence dealing with PPMs is applicable. Even if Eco-labels are voluntary they might violate WTO provisions. If a national eco-Label is not awarded only because of the fact that PPMs do not meet the provisions of this national eco-Label, there might be the same resulting problems as they existed before in the PPMs cases in the GATT and in the WTO. In those cases, the import was restricted or banned by national regulations. In cases in which the national eco-label might have the this potential to restrict or ban the import, the same effect arises. Hence, the application of the WTO jurisprudence for the award of eco-labels based on PPMs must be enforced.

According to this, the view of the DSB of permitting PPMs in the way that they have to meet the 
provisions of the GATT, are also valid for Eco-labels. If an Eco-Label which is awarded because of the PPMs is not justifiable under the provisions of the GATT, it would have to be excused under the regulations of Article XX GATT. In other words, the member state of the WTO, in which Eco-labels based on PPMs are awarded, has to meet the provisions of PPMs made by the jurisprudence of the $\mathrm{WTO}^{[32,33]}$.

Thus, with regard to the jurisprudence of the WTO, the application of Eco-labels is justified. However, to create certainty, the legal situation of this form of labeling has to be regulated by the CTE or the TBTCommittee.

\section{REFERENCES}

1. Markandya, A., 1997. Eco-Labeling: An Introduction and Review. In: Eco-Labeling and International Trade, Zarrilli, S. et al. (Eds.). Palgrave Macmillan, ISBN: 0-333-66547-3, pp: 4.

2. Galarraga, I., 2002. The use of eco-labels: A review of the literature. Eur. Environ., 12: 316-317.

3. Brennan, T.J., 2006. Green preferences as regulatory policy instrument. Ecol. Econ., 56: 144-145.

4. Thøgersen, J., 2000. Psychological determinants of Paying attention to Eco-labels in purchase decisions. Model development and multinational validation. J. Cons. Policy, 23: 285-287.

5. Delbrück, K., 1997. The German Eco-Label "Blue Angel" and International Trade. In: Eco-Labeling and International Trade, Zarrilli, S. et al. (Eds.). ISBN: 0-333-66547-3, pp: 189.

6. Vossenaar, R., 1997. Eco-Labeling and International Trade: The Main Issues. In: EcoLabeling and International Trade, Zarrilli, S. et al. (Eds.). Palgrave Macmillan, ISBN: 0-333-66547-3, pp: 24-25.

7. Galarraga, I., 2002. The use of eco-labels: A review of the literature. Eur. Environ., 12: 324.

8. Markandya, A., 1997. Eco-Labeling: An Introduction and Review. In: Eco-Labeling and International Trade, Zarrilli, S. et al. (Eds.). Palgrave Macmillan, ISBN: 0-333-66547-3, pp: 9.

9. Vossenaar, R., 1997. Eco-Labeling and International Trade: The Main Issues. In: EcoLabeling and International Trade, Zarrilli, S. et al. (Eds.). Palgrave Macmillan, ISBN: 0-333-66547-3, pp: 23.

10. Markandya, R., 1997. Eco-Labeling: An Introduction and Review. In: Eco-Labelling and International Trade, Zarrilli, S. et al. (Eds.). Palgrave Macmillan, ISBN: 0-333-66547-3, pp: 6.
11. Markandya, A., 1997. Eco-Labeling: An Introduction and Review. In: Eco-Labeling and International Trade, Zarrilli, S. et al. (Eds.). Palgrave Macmillan, ISBN: 0-333-66547-3, pp: 2.

12. World Trade Organization, 2001. Ministerial declaration. Proceeding of the Ministerial Conference, Nov. 9-14, WTO, Doha, pp: 1-10. http://www.worldtradelaw.net/doha/mindec.pdf

13 Jha, V. et al., 1997. Eco-Labeling Initiatives as Potential Barriers to Trade: A Viewpoint from Developing Countries. In; Eco-Labeling and International Trade, Zarrilli, S. et al. (Eds.). Palgrave Macmillan, ISBN: 0-333-66547-3, pp: 288.

14. Vossenaar, R., 1997. Eco-Labeling and International Trade: The Main Issues. In; EcoLabeling and International Trade. Zarrilli, S. et al. (Eds.). Palgrave Macmillan, pp: 29.

15. Jha, V. et al., 1997. Eco-Labeling Initiatives as Potential Barriers to Trade: A Viewpoint from Developing Countries. In: Eco-Labeling and International Trade. Zarrilli, S. et al. (Eds.). Palgrave Macmillan, ISBN: 0-333-66547-3, pp: 290.

16. World Trade Law, 1990. Thailand-Restrictions on importation and internal taxes on cigarettes. Report of the Panel. http://www.worldtradelaw.net/reports/gattpanels/th aicigarettes.pdf

17. Shenk, M.D., 1996. United States--standards for reformulated and conventional gasoline. Am. J. Int. Law, 90: 669-674. ttp://www.jstor.org/pss/2203996

18. Wirth, D.R., 1998. European Communitiesmeasures concerning meat and meat products. Am. J. Int. Law, 92: 755-759. http://www.jstor.org/pss/2998141

19. Wirth, D.A., 2002. European Communitiesmeasures affecting asbestos and asbestoscontaining products. Am. J. Int. Law, 96: 435-439. http://www.jstor.org/pss/2693937

20. World Trade Law, 1988. Canada-measures affecting exports of unprocessed herring and salmon. Report of the Panel. http://www.worldtradelaw.net/reports/gattpanels/ca nadaherring.pdf

21. Gaines, S.E., 2002. Processes and production methods: How to produce sound policy for environmental PPM-based trade measures? Columbia J. Environ. Law, 27: 383-416.

22. Condon, B.J., 2006. Environmental Sovereignty and the WTO-Trade Sanctions and International Law. Hotei Publication, ISBN: 1-571-05366-2, pp: 63. 
23. World Trade Law, 1991. United States-restrictions on imports of Tuna (US-Tuna/Dolphin I). Report of the Panel. http://www.worldtradelaw.net/reports/gattpanels/tu nadolphinI.pdf

24. World Trade Organization, 1998. United Statesimport prohibition of certain shrimp and shrimp products. Report of the Panel, WT/DS58/R. http://www.sice.oas.org/DISPUTE/wto/58r00/shriu s.asp

25. General Agreement on Tariffs and Trade, 1988. Canada-restrictions on exports of unprocessed herring and salmon. Report of the Panel, BISD 35/S/98-115, GATT, Geneva.

26. Charnovitz, S., 2002. The law of environmental "PPMs" in the WTO: Debunking the Myth of Illegality. Yale J. Int. Law, 27: 101-102.

27. Hawkins, S., 2008. Skirting protectionism: A GHG-based trade restriction under the WTO. Geo. Int. Environ. L. Rev., 20: 434.

28. World Trade Organization, 2009. Environment: issues-labeling.

http://www.wto.org/english/tratop_e/envir_e/labelli ng_e.htm
29. Markandya, A., 1997. Eco-Labeling: An Introduction and Review. In: Eco-Labelling and International Trade, Zarrilli, S. et al. (Eds.). Palgrave Macmillan, ISBN: 0-333-66547-3, pp: 6.

30. Galarraga, I., 2002. The use of eco-labels: A review of the literature. Eur. Environ., 12: 319-317.

31. World Trade Organization, 2003. The 5th WTO Ministerial Conference, Sept. 10-14, WTO, Cancún, Maxico, pp: 1-1. http://www.wto.org/english/thewto_e/minist_e/min 03_e/min03_e.htm

32. Markandya, A., 1997. Eco-Labeling: An Introduction and Review. In: Eco-Labelling and International Trade, Zarrilli, S. et al. (Eds.). Palgrave Macmillan, ISBN: 0-333-66547-3, pp: 16-17.

33. Campbell, L.B., 1997. International Environmental Standards: Their Role in the Mutual Recognition of Eco-Labeling Schemes. In: Eco-Labeling and International Trade, Zarrilli, S. et al. (Eds.). Palgrave Macmillan, ISBN: 0-333-66547-3, pp: 321. 